\title{
Studies of Human Papovavirus Tumor Antigen in Experimental and Human Cerebral Neoplasms
}

\author{
L. E. BECKER, O. NARAYAN, AND R. T. JOHNSON
}

\begin{abstract}
SUMMARY: Three types of papovaviruses (JC, BK, and $S V 40$ ) have been isolated from man. All three are oncogenic in hamsters, cause frequent infection of man, and share a common $T$ antigen. Augmentation of the expression of $T$ antigen by in vitro cultivation of SV40-induced tumors of hamsters suggested that growing human brain tumors in vitro might provide an effective screening technique for the $S V 40$ virus. In a series of human brain tumors examined in cryostat sections and in tissue culture, $T$ antigen could not be demonstrated, suggesting that by this immunofluorescent technique $S V 40$ was not implicated in the etiology of these tumors.
\end{abstract}

RESUMÉ: Trois types de virus papova (JC, BK et SV40) ont été isolés chez l'humain. Tous les trois sont oncogéniques chez les hamsters, causent de fréquentes infections chez l'homme, et possèdent un antigène $T$ commun. L'augmentation d'expressivité de l'antigène $T$ dans les cultures in vitro de tumeurs causées chez le hamster par le SV40 semble démontrer que les tumeurs humaines en croissance in vitro pourraient servir de technique de dépistage pour le virus SV40. Dans une série de tumeurs cérébrales humaines, l'antigène $T$ fut recherché sans succès dans des sections au cryostat et dans des cultures de tissu. Il semble donc à la lumière des résultats obtenus avec cette technique immunofluorescente que le virus SV40 n'est pas impliqué dans l'étiologie de ce type de tumeur.

From the Departments of Animal Medicine and Neurology, Johns Hopkins School of Medicine, Baltimore, Maryland and the Department of Pathology, University of Toronto, Toronto, Ontario.

Reprint requests to: Dr. L. E. Becker, Hospital for Sick Children, 555 University Avenue, Toronto, Ontario, M5G $1 \times 8$.
The papovaviruses isolated from patients with progressive multifocal leukoencephalopathy

(PML) (Padgett, et al., 1971; Weiner, et al., 1972) must be considered as potential causes of human cerebral neoplasia for several reasons. First, although PML is a demyelinating disease, the unique histological alterations of astrocytes within the lesions resemble those seen in glioblastomas, and cells grown from brains of patients with PML express tumor (T) antigen (Weiner and Narayan, 1973); a case of multifocal glioblastomas has been reported in association with PML (Castaigne, et al., 1974). Second, both JC and SV40 viruses isolated from $P M L$, as well as the related $\mathrm{BK}$ virus isolated from human urine following renal allografts (Gardner, et al., 1971)) are oncogenic for hamsters (Narayan and Weiner, 1974; Walker, et al., 1972; Shah, Daniel and Strandberg, 1975); $\mathrm{JC}$ virus is unique in being more oncogenic when inoculated intracerebrally than by other routes (Walker, et al., 1972). Third, all viruses cause frequent infections of man (Padgett and Walker, 1973; Gardner, 1973; Shah, Daniel and Warszowski, 1973).

Since JC, SV40 and BK viruses have a common $T$ antigen, (Walker, Padgett and ZuRhein, 1972; Takemoto and Mullarkey, 1973) testing for this antigen can form a method of screening for this group of small primate papovaviruses. $T$ antigen has been seen in tissue sections of PML brains, but is more consistently expressed in cells cultured from these brains (Weiner, et al., 1973). The present study includes investigation of the expression of $T$ antigen in cerebral tumors of hamsters induced by a strain of SV40 virus isolated from $\mathrm{PML}$, expression of $\mathrm{T}$ antigen by cells cultivated from these tumors and a preliminary search for $\mathrm{T}$ antigens in human brain tumors.

\section{MATERIALS AND METHODS}

Virus: SV40-PML 1 (EK virus) was originally obtained from cultures of explanted brain from a patient with PML (Weiner, et al., 1972). At the sixth passage level the brain cells, which did not contain infectious virus, were fused to BSC-1 cells using inactivated Sendai virus. The heterokaryon culture was frozen and thawed 4 days after fusion and inoculated onto BSC-1 cells. Within 7 days cytoplasmic vacuolation was followed by pyknosis and degeneration. The culture was frozen and thawed twice, clarified by low speed centrifugation and stored at $-70^{\circ} \mathrm{C}$. Infectivity of this stock virus on BSC-1 cells was $10^{7.0}$ plaque forming units (pfu) per ml.

Animals: Sixty newborn Syrian hamsters were inoculated intracerebrally with $.02 \mathrm{ml}$ of virus ( $10^{5.3}$ pfu per inoculum). Sick animals were sacrificed, and the brain cut through the interhemispheral fissure exposing the tumors. One-third of each tumor was quick frozen in tubes immersed in dry ice and acetone, one-third was finely minced and explanted into culture and one-third was fixed in $10 \%$ buffered formalin. Animals well after 6 months observation were sacrificed, brains were sectioned without fixation and examined grossly for tumors.

Tissue cultures: Tumor fragments were washed 3 times in Hank's balanced salt solution (HBSS), minced, and explanted into Falcon flasks containing Eagles basal 
medium with $10 \%$ fetal bovine serum, $1 \%$ L-glutamine and $1 \%$ penicillin-streptomycin. Confluent monolayers developed within 1 to 2 weeks. Cells were trypsinized and transferred to petri dishes containing 4 coverslips. Coverslips were fixed in acetone for immunofluorescence studies.

Conventional histology: Following formalin fixation brain tumors were paraffin embedded, cut at $5 \mu$, and stained with hematoxylin and eosin $(\mathrm{H} \& \mathrm{E})$ and phosphotungstic acid hematoxylin (PTAH).

Immunofluorescence: The frozen sections of brain tumors were cut at $7 \mu$. Both tissue sections and coverslips were stained with fluorescent antibodies for $\mathrm{T}$ antigen as previously described (Narayan and Weiner, 1974).

Human tumor biopsies: Fragments of human brain tumor obtained at the time of surgery were similarily divided into three parts for explantation into tissue culture, conventional histology and immunofluorescence using the methods described above.

\section{RESULTS}

Oncogenic effects of EK virus in hamster brain

Of the 60 hamsters inoculated with EK virus, 31 developed fibrosarcomas of the scalp and $14 \mathrm{de}-$ veloped intracranial tumors during the 4 to 6 months observation period. All tumors measured from 2 to $5 \mathrm{~mm}$ and filled and distended the ventricular system. Twelve tumors were in the lateral ventricles and 2 in the fourth ventricle. The brain tumors were remarkably similar histopathologically, except for a variation in the degree of differentiation. In the better differentiated tumors, a definite transition from a normal choroid plexus to tumor could be seen, and in some areas the papillary structure of the choroid plexus was covered by tumor cells (Fig. 1). The cells of these papillary tumors were generally small with pleomorphic hyperchromatic nuclei and small amounts of pale basophilic cytoplasm (Fig. 2). In the poorly differentiated tumors, more solid cellular patterns were evident with numerous mitotic cells. Rarely giant cells

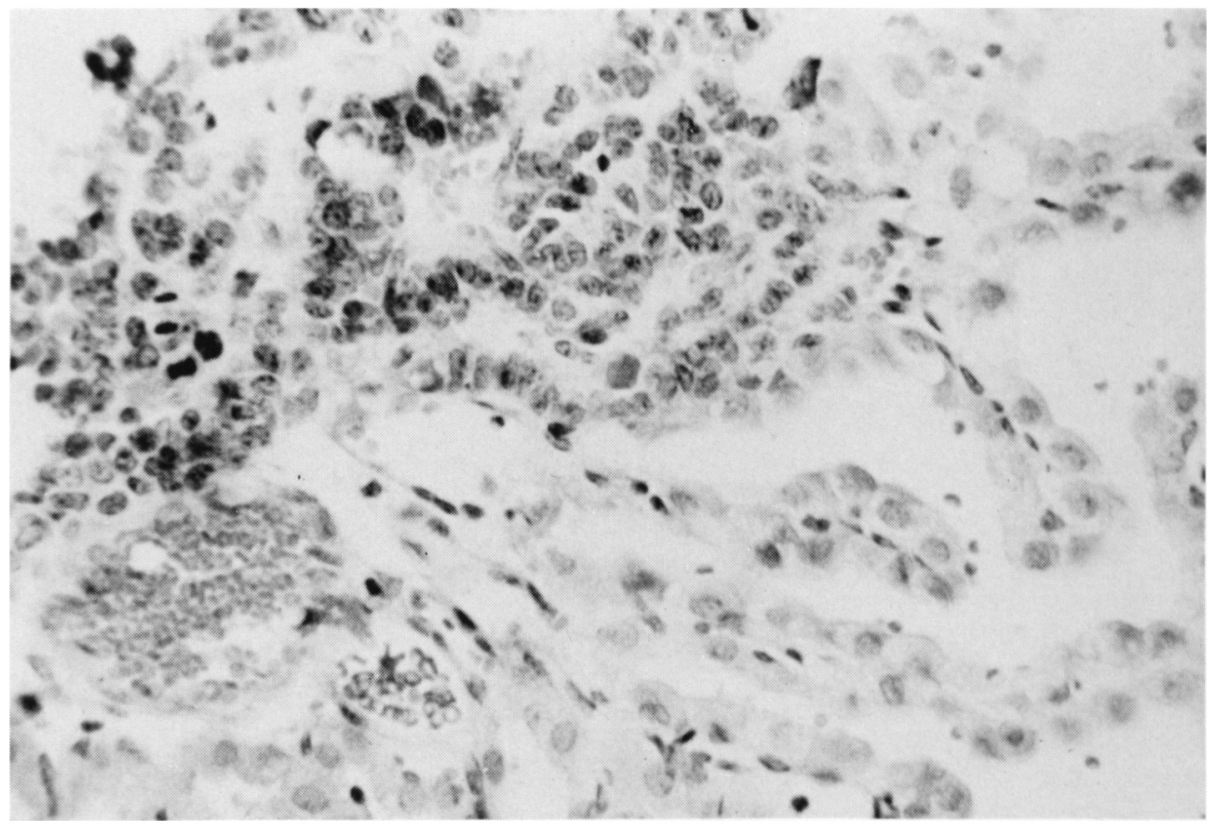

Figure $1-$ In the upper left is an early well differentiated choroid plexus carcinoma showing continuity with normal choroid plexus in the lower right. (250x).

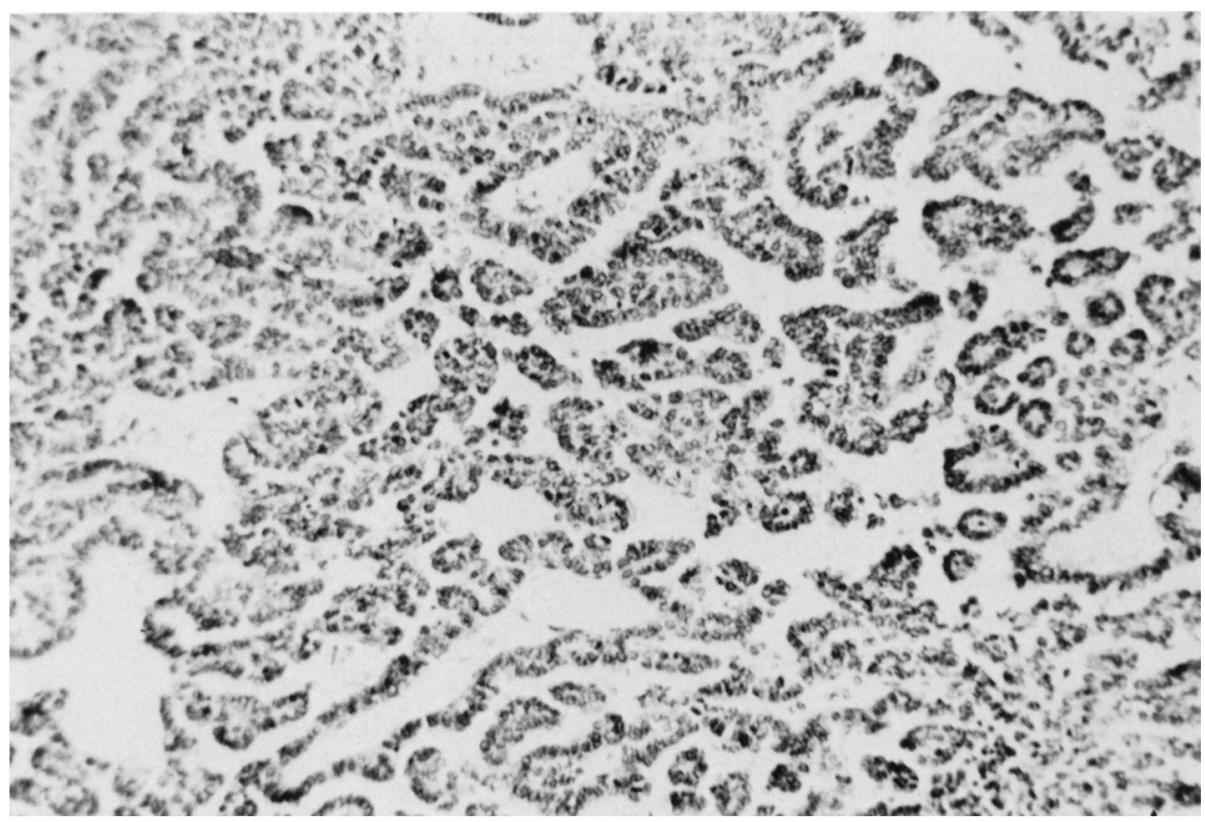

Figure 2-A characteristic well differentiated choroid plexus carcinoma illustrating its epithelial nature with a tendency of the cells to grow around capillaries. $(125 \mathrm{x})$.

and large bizarre mitotic figures were found (Fig. 3). Tumor invaded adjacent neural tissue and spread throughout the ventricles and subarachnoid space. Although many small endothelial cell-lined channels containing red blood cells were present, no true rosettes could be identified. PTAH stain revealed no cilia, blepharoplasts or background fibrillary glia to suggest an ependymal origin of the tumors, confirming that these tumors were of choroid plexus origin.

Expression of $T$ antigen in hamster brain tumors

A remarkable difference in the demonstration of $\mathrm{T}$ antigen in frozen sections of hamster tumors and in cultured cells derived from such tumors was found. No $T$ antigen was detected by fluorescent antibody staining in multiple cryostat cut sec- 


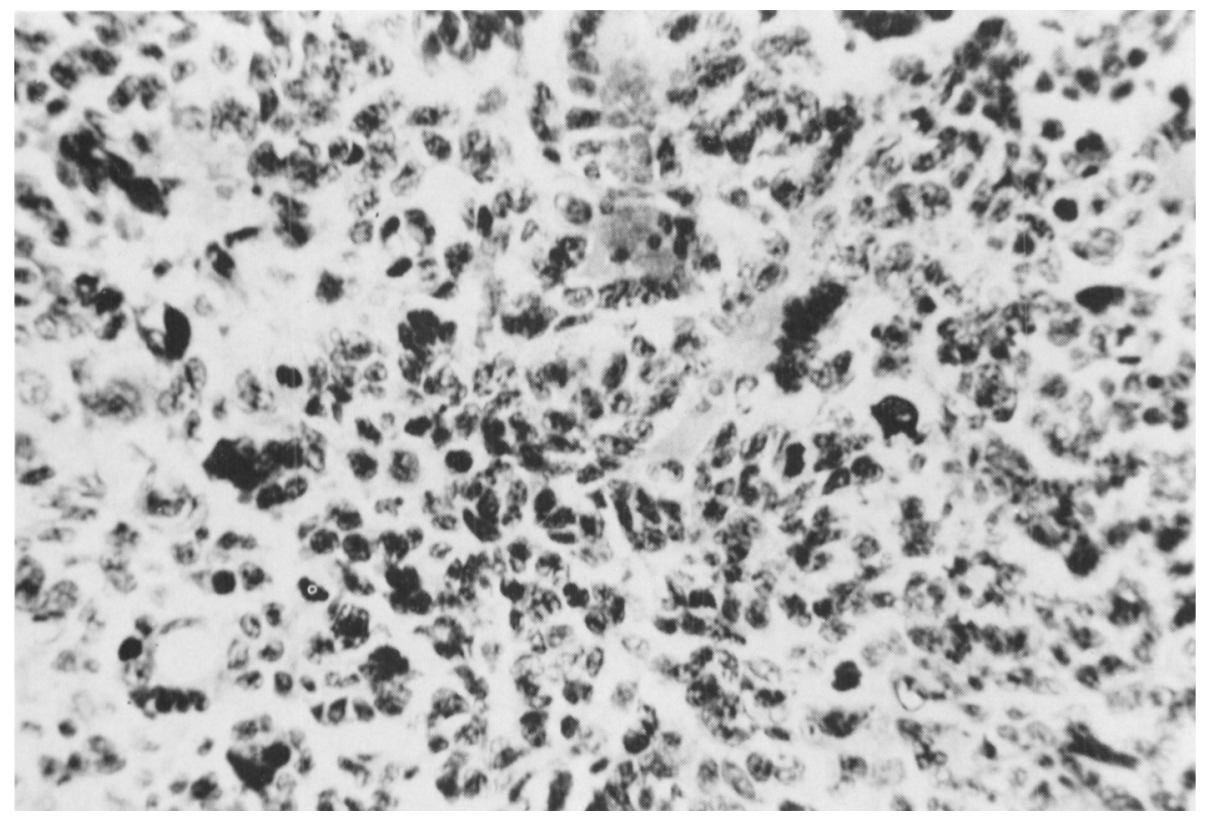

Figure 3-A poorly differentiated choroid plexus carcinoma with marked cellular pleomorphism. (250x).

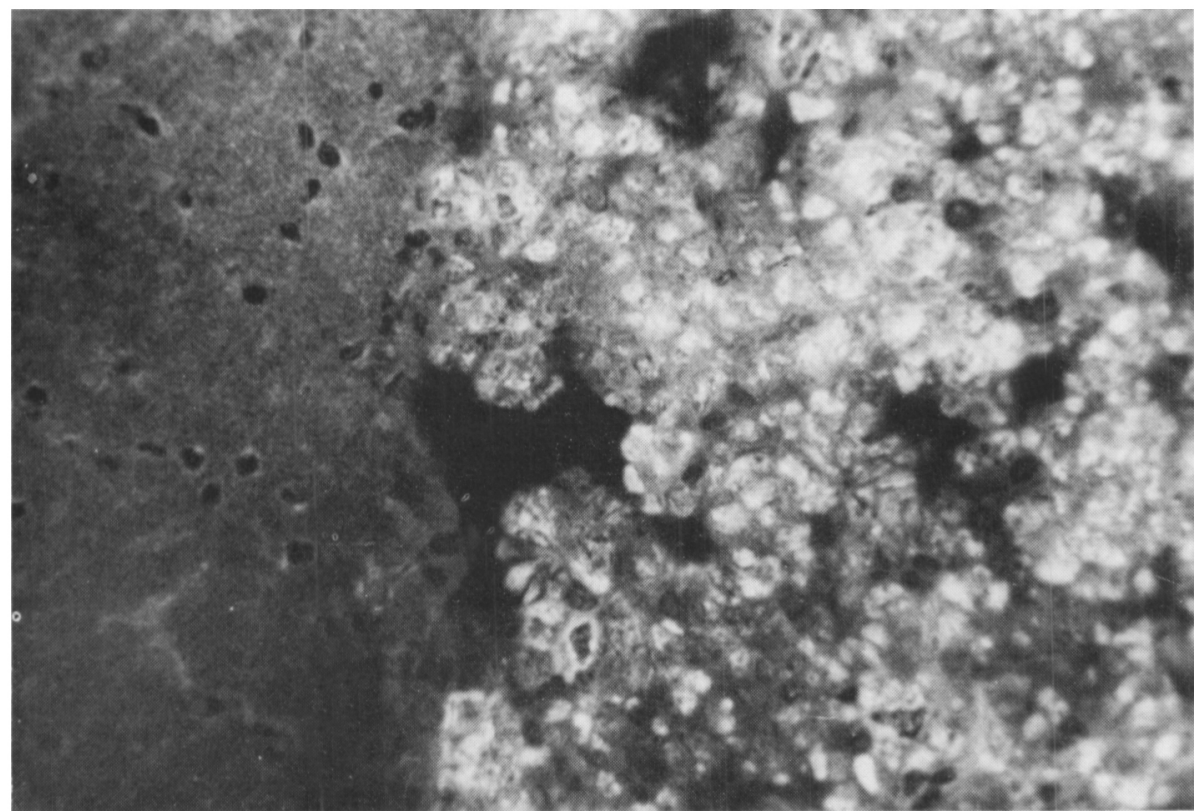

Figure 4-On the left is normal hamster brain and on the right is the $\mathrm{T} \mathrm{Ag}$ immunofluorescent positive tumor. (125x).

tions of 12 of the 14 tumors. In the remaining two tumors intranuclear $\mathrm{T}$ antigen was present in some cells (Fig. 4). In contrast, the cell cultures derived from all 14 tumors showed brilliant nuclear fluorescence in over $95 \%$ of the cells (Fig. 5).

Attempts to demonstrate $\mathrm{T}$ antigens in imprint smears using the method of Diamandopoulas (Diamandopoulas and McLane, 1972) were unsuccessful in some cases and unsatisfactory in others, since cells of these solid tumors failed to adhere to glass.

\section{Examination of human brain tumors for $T$ antigen}

Twenty-nine human brain tumors were studied, including 7 meningiomas, 6 astrocytomas, 6 medulloblastomas, 5 glioblastomas multiforme, 2 ependymomas, 2 schwannomas and 1 hemangioblastoma.
In view of previous studies of human brain cells expressing $\mathrm{T}$ antigen only in subconfluent culture, cells were examined during both the exponential phase of growth and at confluency. No $T$ antigen was detected by fluorescent antibody staining of cryostat sections or of cells cultured from the 29 human tumors. Since non specific nuclear fluorescence does occur, it is important to stress the diagnostic fluorescent pattern of $T$ antigen with consistent sparing of the nucleoli.

\section{DISCUSSION}

$\mathrm{T}$ antigen in sections of choroid plexus tumors of hamsters induced by a human isolate of SV 40 could only rarely be demonstrated. In contrast, $T$ antigen could readily be demonstrated by fluorescent antibody staining of over $95 \%$ of cells grown from these tumors. This finding suggested that screening brain tumors by indirect immunofluorescence using frozen sections would not be reliable, necessitating the use of in vitro tumor cells. In vitro augmentation of $T$ antigen expression did not appear to result from selective growth of tumor cells containing the antigen, since over $95 \%$ of cells from tumors in which $\mathrm{T}$ antigen could not be demonstrated expressed $T$ antigen within hours of cultivation in vitro. $T$ antigen is coded by the SV40 virus genome which has been integrated into the host cell chromosomes. Kinetic studies show that $T$ antigen appears 8-12 hours after infection with SV40 prior to the appearance of detectable amounts of viral DNA (Butel, Tevethia and Melnick, 1972), so its appearance does not depend on viral replication. $T$ antigen is located in the nucleus of interphase cells but is not associated with the condensed chromosomes. It is a heat labile protein with an estimated molecular weight of 70,000 (Del Villano and Defendi, 1973). Results from others (Stenman, Zeuther and Ringertz, 1975) comparing the relative amount of immunofluorescent $T$ antigen with microspectrophotometric DNA determinations have shown that the expression of the gene for $T$ antigen in trans- 


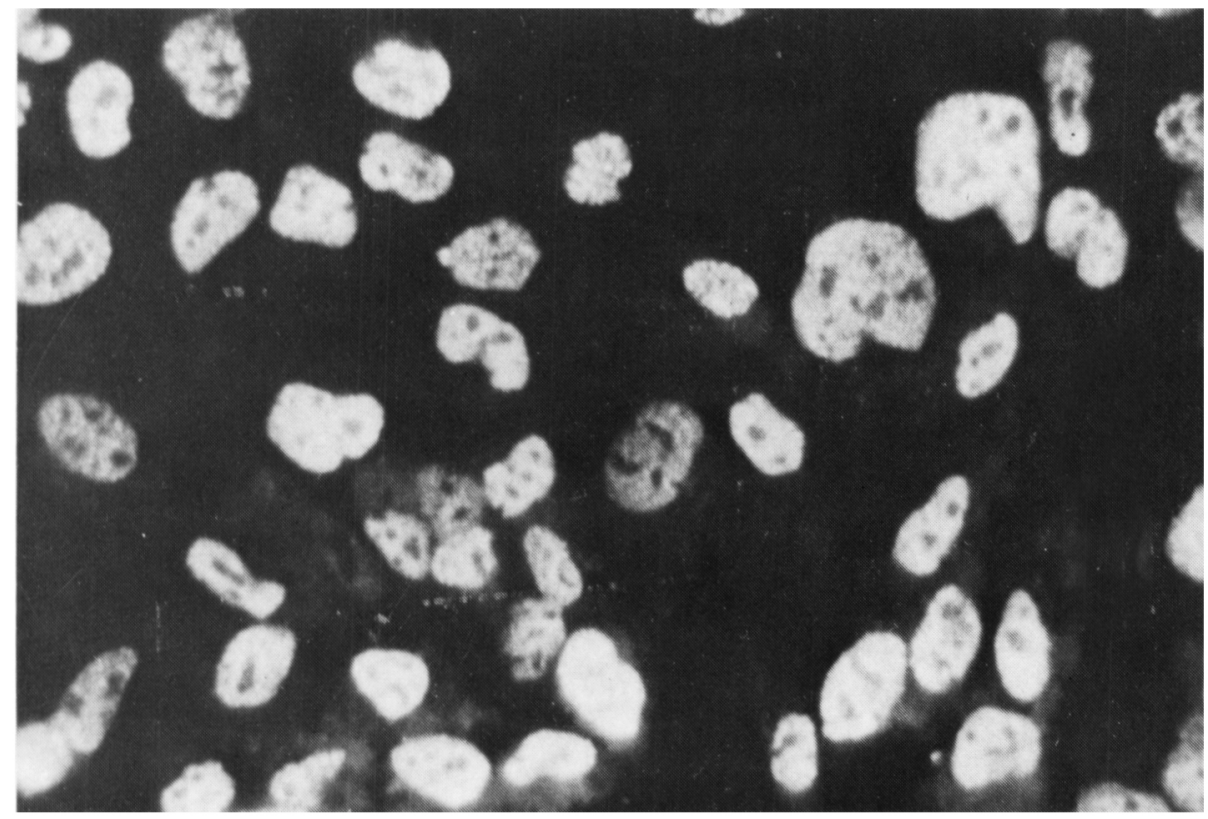

Figure 5-This is a cell monolayer of hamster tumor cells illustrating positive $\mathrm{T} \mathrm{Ag}$ immunofluorescence with characteristic nucleolar sparing. (400x).

formed cells increased during cellular DNA replication reaching its highest level in G2 nuclei. The increase in expression of $T$ antigen in vitro compared to in vivo tumor growth may be accounted for by an increase in the number of in vitro cells undergoing mitosis.

SV 40 and JC, both can cause cerebral neoplasms in hamsters. JC virus induces tumors in newborn hamsters resembling medulloblastomas and gliomas of man (Walker et al., 1972). The human isolate of SV40 virus used in this study caused only choroid plexus tumors. Although previous studies of monkey isolates refer to virus induced ependymomas (Eddy, 1962; Gerber and Kirschstein, 1962), these tumors do not appear different from those caused by EK virus and the difference probably is solely one of morphological interpretation (Duffell, Hinz and Nelson, 1964).

The failure to detect $\mathrm{T}$ antibody in cancer patients has been sited as evidence that SV40-related viruses are not involved in human neoplasia (Shah, 1972). However, the small tumor mass and relative inaccessability to immunologic systems of cerebral tumors, and the failure of patients with PML to have antibodies against $T$ anitgen, all make this conclusion questionable. In a study by Weiss et al., (1975) two out of seven meningiomas tested in cell cultures were felt by indirect immunofluorescence to show $\mathrm{T}$ antigen. In addition, a hemaglutinating ticulum cell sarcoma of the brain and from the urine of a patient with Wiskott-Aldrich syndrome. However, fluorescent tests with SV40 T antibody on frozen tissue sections of the sarcoma were negative (Takemoto et al., 1974). Since T antigen of primate papovaviruses of SV40-polyoma subgroup cross react, staining for $T$ antigen provided a simple screening procedure to examine the possible role of these agents in human cancer. In the 29 brain tumors examined in this series, no $T$ antigen was demonstrated, suggesting that by this immunofluorescent technique SV40 was not implicated in the etiology of these tumors.

\section{REFERENCES}

BUTEL, J. S., TEVETHIA, S. S. and MELNICK, J. L. (1972). Oncogenicity and cell transformation by papovavirus SV40. The role of the viral genome. Advances in Cancer Research 15, 1-55.

CASTAIGNE, P., RONDOT, P., ESCOUROLLE, R., RIBADEAU DUMAS, J. L., CATHALA, F. and HAUW, J. J. (1974). Revue Neurologique 130, 379-392. papovavirus was isolated from a re-
DEL VILLANO, B. C. and DEFENDI, $V$. (1973). Characterization of the SV40 T antigen. Virology 51, 34-46.

DIAMANDOPOULOS, G. T. and MCLANE, M. F. (1972). The tumour imprint technique for demonstrating SV40 T antigen by immunofluorescence. Proceedings of the Society for Experimental Biology and Medicine. 141, 62-66.

DUFFELL, D., HINZ, R. and NELSON, E. (1964). Neoplasms in hamsters induced by Simian virus 40 . American Journal of Pathology, 45, 59-71.

EDDY, B. K. (1962). Tumours produced in hamsters by SV40. Federation Proceedings. 21, 930-935.

GARDNER, S. D., FIELD, A. M., COLEMAN, D. V. and HULME, B. (1971). New human papovavirus (B.K.) isolated from urine after renal transplantation. Lancet 1, 1253-1257.

GARDNER, S. D. (1973). Prevalence in England of antibody to human polyoma virus (B.K.). British Medical Journal I, 77-78.

GERBER, P. and KIRSCHSTEIN, R. L. (1962). SV40-induced ependymomas in newborn hamsters. Virology 18, 582-588.

NARAYAN, O. and WEINER, L. P. (1974). Biological properties of two stains of Simian virus 40 isolated from patients with progressive multifocal leukoencephalopathy. Infection and immunity 10 , 173-179.

PADGETT, B. L., WALKER, D. L., ZURHEIN, G. M. and ECHROADE, R. J. (1971). Cultivation of papova-like virus from human brain with progressive multifocal leukoencephalopathy. Lancet 1, 1257-1260.

PADGETT, B. L. and WALKER, D. L. (1973). Prevalence of antibodies in human sera against J.C. virus, an isolate from a case of progressive multifocal leukoencephalopathy. The Journal of Infectious Diseases $127,467-470$.

RABSON, A. S., O'CONNER, G. J. and KIRSCHSTEIN, R. L. (1962). SV40 induced ependymomas in newborn hamsters. Virology 18, 582-588.

SHAH, K. V. (1972). Evidence for a SV 40 related papovavirus infection of man. American Journal of Epidemiology 95, 199-206.

SHAH, K. V., DANIEL, R. W. and WARSZOWSKI, R. M. (1973). High prevalence of antibodies to BK virus, and SV40 related papovavirus in residents of Maryland. The Journal of Infectious Diseases 128, 784-787.

SHAH, K. V., DANIEL, R. W. and STRANDBERG, J. D. (1975). Sarcoma in a hamster inoculated with B.K. virus, a human papovavirus. Journal of the National Cancer Institute 54, 945-950.

STENMAN, S., ZEUTHER, J. and RINGERTZ, R. N. (1975). Expression of SV40 $T$ antigen during the cell cycle of SV40transformed cells. International Journal of Cancer 15, 547-554.

TAKEMOTO, K. K. and MULLARKEY, M. F. (1973). Human papovavirus, BK 
strain: Biological studies including antigenic relationship to simian virus 40 . Journal of Virology 12, 625-631.

TAKEMOTO, K. K., RABSON, A. S., MULLARKEY, M. F., BLAESE, R. M., GARON, C. F. and NELSON, D. (1974). Isolation of papovavirus from brain tumour and urine of a patient with Wiskott Aldrich Syndrome. Journal of the National Cancer Institute 53, 1205-1207.

WALKER, D. L., PADGETT, B. L., ZURHEIN, G. M., ALBERT, A. E. and MARSH, R. F. (1972). Human papovavirus
(JC): Induction of brain tumours in hamsters. Science 181, 674-676.

WEINER, L. P., HERNDON, R. M., NARAYAN, O., JOHNSON, R. T., SHAH, K. V., RUBENSTEIN, L. J., PREZIOSI, T. J. and CONLEY, F. K. (1972). Virus related to SV40 in patients with progressive multifocal leukoencephalopathy. The New England Journal of Medicine 286, 385.390.

WEINER, L. P. and NARAYAN, O. (1973). A papovavirus isolated from patients with progressive multifocal leukoence- phalopathy. Annals of Clinical Research 5 . 279-282.

WEINER, L. P., NARAYAN, O., PENNEY, J. B., HERNDON, R. M., FERINGA. E. R., TOURTELLOTTE. $W$. $W$. and JOHNSON, R. T. (1973). Papovavirus of J.C. type in progressive multifocal leukoencephalopathy. Archives of Neurology 29, 1-3.

WEISS, A. F., PORTMANN. R.. FISCHER, H., SIMON, J. and ZANG, K. D. (1975). Simian virus 40 -related antigen in three human meningiomas with defined chromosome loss. Proceedings of the National Academy of Science 72, 609-613. 